\title{
Spillover from marine reserves: the case of Naso vlamingii at Apo Island, the Philippines
}

\author{
Garry R. Russ ${ }^{1, *}$, Angel C. Alcala ${ }^{2}$, Aileen P. Maypa ${ }^{2}$ \\ ${ }^{1}$ School of Marine Biology and Aquaculture, James Cook University, Townsville, Queensland 4811, Australia \\ ${ }^{2}$ Silliman University Angelo King Center for Research and Environmental Management, Silliman University, \\ Dumaguete City 6200, Philippines
}

\begin{abstract}
The use of no-take marine reserves as fisheries management tools is controversial. A major expectation of marine reserves is that they will become net exporters of adult biomass (the 'spillover effect'). Herein, we show that the biomass of the surgeonfish Naso vlamingii tripled over 18 yr (1983 to 2001) in a reserve at Apo Island, Philippines. Over time, the biomass of N. vlamingii increased by a factor of 40 outside but close to the reserve boundaries (200 to $250 \mathrm{~m}$ ) but not at greater distances (250 to $500 \mathrm{~m}$ ). In 2000/2001 hook-and-line catch per unit effort (CPUE) for $N$. vlamingii was 45 times higher within $200 \mathrm{~m}$ of the reserve boundary than for all other fishing grounds combined, with $62.5 \%$ of the hook-and-line catch records being recorded within $200 \mathrm{~m}$ either side of the reserve, in just $11 \%$ of the reef fishing area. This comprises some of the best evidence that reserves can benefit fisheries by spillover.
\end{abstract}

KEY WORDS: Marine reserves $\cdot$ Fisheries management $\cdot$ Naso vlamingii $\cdot$ Philippines $\cdot$ Spillover

\section{INTRODUCTION}

No-take marine reserves are areas of the marine environment in which all forms of extraction and disturbance by humans are permanently banned (Roberts \& Hawkins 2000, Gell \& Roberts 2002). Marine reserves are promoted widely as conservation and fisheries management tools (Roberts \& Polunin 1991, Dayton et al. 2000, Roberts \& Hawkins 2000, Gell \& Roberts 2002, Russ \& Zeller 2003). However, their use as fisheries management tools is controversial (Gell \& Roberts 2002, Hilborn 2002), the main expectation being that they will help to sustain external fisheries by net exportation of adults (the 'spillover effect') and propagules (the 'recruitment effect') (Russ 2002). Spillover and recruitment effects are likely to require long periods of time to fully develop (McClanahan \& Mangi 2000, Jennings 2001, Russ 2002). Recovery periods for exploited species inside no-take marine reserves will depend upon a large number of factors. These include initial population size, intrinsic rate of population increase $(r)$, life-history characteristics, the success of individual recruitment events, rates of immigration into reserves, and the extent of reduction of fishing mortality $(F)$ in a reserve (Jennings 2001). For coral reef fish, we now know that maximum potential longevities are in the order of 10 to $40 \mathrm{yr}$ for many species (Choat \& Axe 1995, Cappo et al. 2000, Choat \& Robertson 2002). This suggests that the time required for population recovery and the development of spillover, a process often assumed to be driven by densitydependent effects inside reserves (Sanchez Lizaso et al. 2000), may involve decades.

No study has unequivocally demonstrated spillover (net export of adults) from a marine reserve (Russ 2002), partly because of the lack of appropriate experimental designs (e.g. lack of information on spatial abundance, spatial catch rate and movement patterns of targeted species before and after reserve establishment). Also, few investigations of spillover from reserves have been continued long enough for an effect to develop fully. In studies of spillover from coral reef reserves, studies generally cover a decade or less. For example, the studies of McClanahan \& Kaunda-Arara 
(1996) and McClanahan \& Mangi (2000) in Kenya, Russ \& Alcala (1996) in the Philippines, Roberts et al. (2001) in St. Lucia, and Galal et al. (2002) in Egypt, spanned $6,7,10,5$ and $5 \mathrm{yr}$, respectively. All these studies produced evidence consistent with spillover. However, since many species of coral reef fishes are relatively long-lived, spillover from many coral reef reserves may well take decades to develop fully. The only study to date to investigate spillover of tropical reef fishes from a reserve on a time scale of decades is that of Roberts et al. (2001) in Florida, which showed that export of record-sized fishes to hook-and-line fisheries outside the Merritt Island no-take reserve took 9, 27 and $31 \mathrm{yr}$ to develop for spotted sea trout, red drum and black drum, respectively. These 3 species had

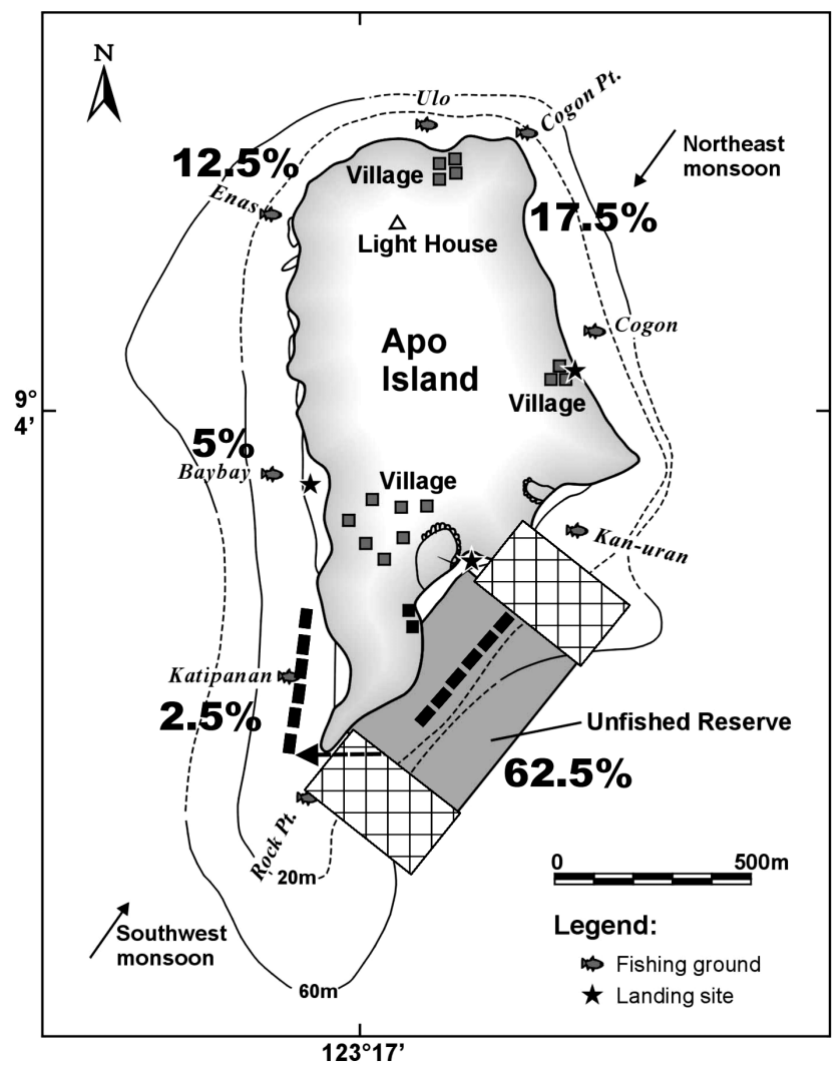

Fig. 1. Map of Apo Island, the Philippines, showing location of no-take reserve (shaded box) and positions of replicate $50 \times$ $20 \mathrm{~m}$ underwater visual census (UVC) plots ( $\mathbf{(})$ in the reserve and fished nonreserve site at Katipanan, the major fishing grounds around the island, and the major fish-landing sites. Black squares on land fronting the reserve represent the Marine Management Center and the Department of Environment and Natural Resources buildings. Cross-hatched area is the $200 \mathrm{~m}$ area on each side of the reserve, with dashed arrow indicating $200 \mathrm{~m}$ distance from southern boundary of the reserve directly to first UVC replicate plot at the nonreserve site. Percentage hook-and-line catch records of the surgeonfish Naso vlamingii in 2000/2001 are shown for various locations around island maximum potential longevities of 15,35 and $70 \mathrm{yr}_{\text {, }}$ respectively.

Over a period of $18 \mathrm{yr}$ (1983 to 2001), we monitored the biomass of an exploited surgeonfish, Naso vlamingii, inside a no-take marine reserve at Apo Island, the Philippines, and at a site on the island open to fishing. We also measured the change in spatial distribution of biomass outside the reserve over this period, and the spatial distribution of the hook-and-line catch rate of this fish outside the reserve after 18 to $19 \mathrm{yr}$ of reserve protection. Herein, we determine if this information is consistent with spillover of $N$. vlamingii (a fish with a maximum potential longevity of $40 \mathrm{yr}^{\text {; }}$ Choat \& Axe 1995) over a period of almost 2 decades.

\section{MATERIALS AND METHODS}

The study was conducted at Apo Island, central Philippines $\left(9^{\circ} 4^{\prime} \mathrm{N}, 123^{\circ} 17^{\prime} \mathrm{E}\right)$ (Fig. 1) from 1983 to 2001. The island covers an area of $0.74 \mathrm{~km}^{2}$, with $1.06 \mathrm{~km}^{2}$ of coral reef down to the $60 \mathrm{~m}$ isobath (Russ \& Alcala 1998). Only traditional fishing methods, nondestructive to the benthos, have been allowed on the island since 1986, i.e. hook-and-line, gill nets, spears, and bamboo traps. A $0.45 \mathrm{~km}$ long 'no-take' marine reserve lies along the southeastern portion of the island (Fig. 1), occupying approximately $10 \%$ of the coral reef area. The reserve has been protected since 1982, and Apo Island observes strict implementation of reserve regulations (Russ \& Alcala 1999).

Estimates of biomass were made at the reserve and a nonreserve (fished) site (Fig. 1) in December or November of each year from 1983 to 2001, except for the years 1984, 1986 to 1987 and 1996 using an underwater visual census (UVC) method, details of which have been published elsewhere (Russ \& Alcala 1998). Six $1000 \mathrm{~m}^{2}(50 \times 20 \mathrm{~m})$ replicate areas of reef slope were censused in the reserve ( 2 to $17 \mathrm{~m}$ depth) and at the fished nonreserve site (6 to $17 \mathrm{~m}$ ) on each sampling occasion. The observer (G.R.R.), the UVC method and the position of the replicates were the same from 1983 to 2001 (except that some replicate areas at the nonreserve site differed between 1983 and all other times). The $50 \times 20 \mathrm{~m}$ replicate areas were distributed evenly along the northern section of the reserve (Fig. 1), and were placed within approximately $10 \mathrm{~m}$ of each other to ensure that 6 replicates would sample most (>80\%) of the reserve. The nonreserve (fished control) site at Katipanan fishing ground (Fig. 1) was originally chosen as the closest site to the reserve with a benthic habitat as similar as possible to the reserve itself, and offered all-weather access to diving. The $50 \times 20 \mathrm{~m}$ replicate areas were distributed in the same way as those in the reserve (Fig. 1). Counts and estimates of 
total length $( \pm 5 \mathrm{~cm})$ of Naso vlamingii were made. Juveniles $(<10 \mathrm{~cm})$ were not counted. An estimate of biomass was made from density and size-structure data and a length-weight relationship $(0.0262 \times$ (Total Length) ${ }^{2.97}$ ) estimated for large Naso species (Froese \& Pauly 1997). The spatial distribution of fish biomass over time at the nonreserve site was estimated using the methods described by Russ \& Alcala (1996). Estimates of biomass were made for each replicate $50 \times$ $20 \mathrm{~m}$ plot in the nonreserve area (Fig. 1), and were averaged for the period 1985 to 1988 (early phase of reserve protection) and 1990 to 2001 (mid-to-late phase of reserve protection). The 1983 nonreserve data were excluded from this analysis.

Spatial hook-and-line catch per unit effort (CPUE) for Naso vlamingii was estimated by roving creel surveys in 2000 and 2001 (Maypa et al. 2002). All fishermen used hook-and-line and this gear accounted for most of the catch during this period (Maypa et al. 2002). Field observers collected data from January to December of each year. Catches of $N$. vlamingii from within the $60 \mathrm{~m}$ isobath line were recorded. Weight measurements of fresh fish were made by A.P.M. and a fish dealer living on the island who had been trained to identify fish species using local names. Fish landed were weighed with commercial weighing scales to the nearest $10 \mathrm{~g}$. When fishermen would not allow either length or weight measurements of their catch to be made, their estimate of the fish weight was recorded. Catch surveys used fish-landing forms that recorded (1) name of fisherman, (2) date, (3) total fishing hours, (4) fishing ground, (5) manpower, (6) gear used, (7) total weight of $N$. vlamingii caught (but not number of individuals caught). This information allowed estimates of spatial variations in catch records and CPUE around the island. At Apo Island, fishermen land their catch at many different sites, making it difficult to record every fish landing. We therefore monitored 3 major landing sites (Fig. 1). CPUE data were collected on 3 randomly chosen days in each week of the year.

The effects of reserve status and time on Naso vlamingii biomass were analyzed by a repeatedmeasures analysis of variance (ANOVA), since the same 6 replicate areas were censused at the reserve and nonreserve sites at each sampling time. Biomass data were $\log (x+1)$-transformed to satisfy assumptions of the analysis, and temporal trends in the reserve and nonreserve were examined by linear regression. The significance of changes in the spatial distribution of the biomass of $N$. vlamingii over time at the nonreserve site was tested by a chi-square test. Using a Mann Whitney $U$-test, hook-and-line CPUE for $N$. vlamingii within $200 \mathrm{~m}$ of the reserve boundary was compared to that at all other fishing grounds combined in $2000 / 2001$.

\section{RESULTS}

A repeated-measures ANOVA indicated significant effects of reserve $\left(F_{1,10}=75.41, \mathrm{p}<0.001\right)$ and time $\left(F_{13,130}=1.80, \mathrm{p}<0.05\right)$ on the log-transformed biomass of Naso vlamingii. The reserve $\times$ time interaction was not significant $\left(F_{13,130}=1.41, \mathrm{p}=0.16\right)$ for this analysis. The biomass of $N$. vlamingii tripled inside the reserve over $18 \mathrm{yr}$ of protection from fishing (Fig. 2a; mean biomass $=1.02 \times$ years protection $+6.60, \mathrm{r}^{2}=0.58, F_{1,12}=$ $16.81, \mathrm{p}<0.01)$. There was no clear pattern of change in biomass at the fished site over the same period (Fig. 2a, mean biomass $=-0.05 \times$ years fished +3.18 , $\mathrm{r}^{2}=0.01, F_{1,11}=0.06, \mathrm{p}=0.81$ ). The slopes of the plots in Fig. 2a differ significantly (Student's $t$-test, $t_{23} \mathrm{df}=$ $3.28, \mathrm{p}<0.01$ ), indicating a significant interaction be-
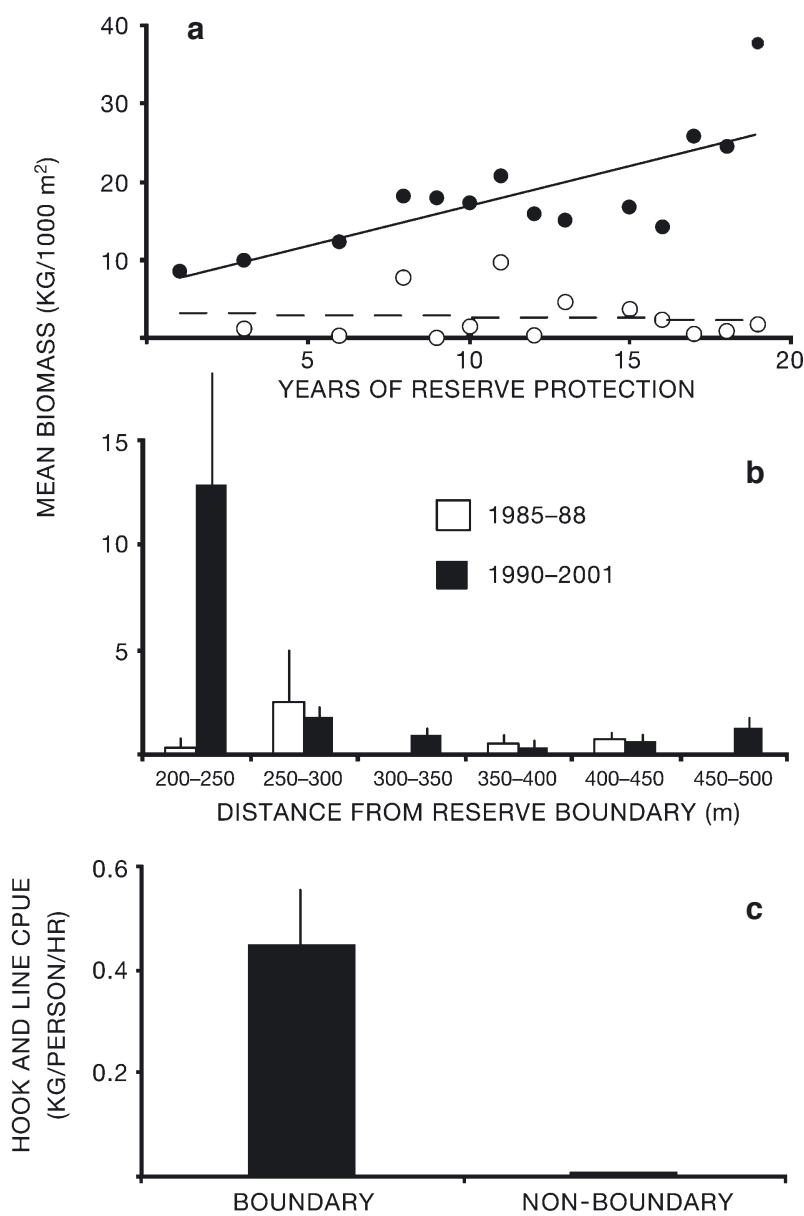

Fig. 2. Naso vlamingii. (a) Biomass in no-take reserve (•) and the fished nonreserve (O) at Apo Island from 1983 to 2001 (reserve) and 1985 to 2001 (nonreserve); (b) biomass at nonreserve site at different distances from reserve boundary in early (1985 to 1988) and late (1990 to 2001) phases of reserve protection; (c) hook-and-line catch per unit effort (CPUE) close to (within $200 \mathrm{~m}$ ) and some distance from $(>250 \mathrm{~m}$ ) reserve in 2000 to 2001. Error bars in (b) and (c) are standard errors 
Table 1. Spatial distribution of hook-and-line fishing effort $\left(\right.$ person $\left.^{-1} \mathrm{~h}^{-1}\right), \%$ effort (proportion of total person hours), number of Naso vlamingii catch records, and catch-per-unit-effort (CPUE; records person ${ }^{-1} \mathrm{~h}^{-1}$ ) at 8 fishing grounds around Apo Island (see Fig. 1) for 2000 and 2001 combined. Data recorded from fisherman interviews at the 3 major landing sites. Note that 1 catch record may represent more than 1 fish. Each interview recorded species, total weight of catch of that species, total hours fished, but not number of individual fish caught. Also note that CPUE is expressed as $\mathrm{kg} \mathrm{person}^{-1} \mathrm{~h}^{-1}$ in Fig. 2. 'Boundary' fishing ground was $200 \mathrm{~m}$ on either side of Apo Reserve

\begin{tabular}{|c|c|c|c|c|c|c|c|c|c|}
\hline \multirow[t]{2}{*}{ Record } & \multicolumn{8}{|c|}{ — Fishing ground - } & \multirow[t]{2}{*}{ Total } \\
\hline & Boundary & Katipanan & Baybay & Enas & Ulo & Kasorenyo & Cogon & Kanuran & \\
\hline No. of interviews recording fishing ground & 64 & 5 & 25 & 334 & 34 & 41 & 157 & 4 & 664 \\
\hline Fishing effort & 172.6 & 17.6 & 97.6 & 1414 & 98.6 & 163.6 & 465.1 & 7.9 & 2437 \\
\hline$\%$ effort & 7.0 & 0.7 & 4.0 & 58.2 & 4.1 & 6.7 & 19.0 & 0.3 & 100 \\
\hline No. of catch records & 25 & 2 & 1 & 5 & 0 & 0 & 7 & 0 & 40 \\
\hline$\%$ of catch records & 62.5 & 5 & 2.5 & 12.5 & 0 & 0 & 17.5 & 0 & 100 \\
\hline CPUE & 0.15 & 0.11 & 0.01 & 0.004 & 0 & 0 & 0.02 & 0 & \\
\hline
\end{tabular}

tween reserve status and time. This is consistent with the hypothesis that the removal of fishing pressure caused an increase in fish biomass in the reserve.

Over time, the biomass of Naso vlamingii increased by a factor of 40 outside but close to the reserve boundary $(200$ to $250 \mathrm{~m})$, but not at greater distances (250 to $500 \mathrm{~m}$ ) (Fig. 2b, chi square $5 \mathrm{df}=9.58,0.1>$ p > 0.05). In 2000 to 2001, hook-and-line CPUE for N. vlamingii was 45 times higher within $200 \mathrm{~m}$ of the reserve boundary than for all other fishing grounds combined (Fig. 2c, Mann-Whitney $U_{25,25 \mathrm{df}}=87.50, \mathrm{p}<0.01$ ), with $62.5 \%$ of the hook-and-line catches being recorded within $200 \mathrm{~m}$ either side of the reserve, in just $11 \%$ of the reef fishing area (Fig. 1).

The spatial distribution of hook-and-line fishing effort, catch records of Naso vlamingii, and catch rate of $N$. vlamingii (as catch records person ${ }^{-1} \mathrm{~h}^{-1}$ ) are shown in Table 1. Fishing effort was not distributed evenly around the island. In 2000 to 2001, over $75 \%$ of the hook-and-line effort was recorded at the Enas and Cogon sites, on the north side of the island (Fig. 1). However, $62.5 \%$ of the $N$. vlamingii hook-and-line catch records in 2000 to 2001 were recorded within $200 \mathrm{~m}$ either side of the reserve (Table 1, Fig. 1). The catch rate of $N$. vlamingii at the Katipanan fishing site, where the UVC control area was located (Fig. 1), was comparable to that recorded in an area extending $200 \mathrm{~m}$ on either side of the reserve boundary (Table 1, Fig. 1). However, the Katipanan estimate was based on only 2 catch records (Table 1 ).

\section{DISCUSSION}

This study presents some of the most convincing evidence for spillover to date. The findings are consistent with spillover of Naso vlamingii from Apo Reserve developing gradually and influencing the local fishery in a positive manner. This study is unique in that it is the only one to have monitored biomass buildup of a species targeted by fisheries inside and immediately adjacent to a no-take reserve over time scales likely to be appropriate for many long-lived reef fish, i.e. over decades.

Nevertheless, the evidence is equivocal for 2 reasons. Firstly, the spatial distribution of hook-and-line CPUE for Naso vlamingii was not measured at Apo Island before the reserve was established in 1982. Secondly, movement patterns of $N$. vlamingii were not measured to detect if such patterns shifted over the 2 decades from non-directed movements before the reserve existed to net export from the reserve as biomass increased in the reserve. The former was a factor that we had overlooked. The latter was difficult to verify, since our decision not to do manipulative research, such as capturing and tagging fishes in the reserve, was critical in convincing the local community that the reserve is truly a no-take area set up for their benefit. Furthermore, no study has yet demonstrated that a reserve has caused a significant change in the movement patterns of reef fishes over such time scales.

Between 1983 and 2001, the biomass of Naso vlamingii tripled inside the reserve (Fig. 2a), whereas outside, but close to the reserve boundary, it increased by a factor of 40. This seemingly incongruous result arose from the fact that the reserve had a healthy coral reef slope habitat, and reasonable $N$. vlamingii biomass $\left(8.42 \mathrm{~kg} 1000 \mathrm{~m}^{-2}\right)$ in 1983, i.e. $1 \mathrm{yr}$ after the reserve had been established. In other words, N. vlamingii biomass was relatively high in the reserve to begin with. Outside the reserve, the initial (1985 to 1988) $N$. vlamingii biomass at 200 to $250 \mathrm{~m}$ from the reserve boundary was very low $\left(0.32 \mathrm{~kg} 1000 \mathrm{~m}^{-2}\right)$. Over the $18 \mathrm{yr}$ study period, $N$. vlamingii biomass increased from 8.42 to $37.62 \mathrm{~kg} 1000 \mathrm{~m}^{-2}$ (a 4.5 -fold increase) inside the no-take reserve, whereas outside, but close (200 to $250 \mathrm{~m}$ ) to the reserve boundary, biomass increased from 0.32 to $12.90 \mathrm{~kg} 1000 \mathrm{~m}^{-2}$ (a 40-fold 
increase); i.e. the biomass attained outside but close to the reserve boundary was similar to that initially in the reserve.

Clearly, the effect of spillover in this study was not sufficient to concentrate most of the hook-and-line fishing at Apo Island close to the reserve boundary (Table 1). Most fishing occurs on the northern side of the island, one critical reason being that the NE and SW monsoon seasons dominate local fishing patterns. A large part of the catch is taken during the SW Monsoon (June to September) and the interim calm periods (April, May and October) between the monsoons (Bellwood 1988, Maypa et al. 2002). Most of the Carangidae (jacks) at Apo Island (which constitute 23 to $47 \%$ of the total catch at the island) are caught on the north of the island, far from the reserve, during the SW monsoon and the interim periods of calm (Bellwood 1988, Maypa et al. 2002). It is here also that the mainstream currents first encounter the reef (Bellwood 1988, Maypa et al. 2002).

Several other studies have produced convincing evidence in support of spillover from coral reef and temperate marine reserves. Such evidence is usually higher abundance or catch rates of exploited species immediately adjacent to reserve boundaries (McClanahan \& Kaunda-Arara 1996, Rakitin \& Kramer 1996, Russ \& Alcala 1996, Cole et al. 2000, McClanahan \& Mangi 2000, Roberts et al. 2001, Galal et al. 2002, Kelly et al. 2002). In one of the more long-term studies, Davidson (2001) detected increased hook-andline CPUE of blue cod Parapercis colias inside, but not outside, the Long Island-Kokomohua marine reserve in New Zealand over a $6.5 \mathrm{yr}$ period. However, the control (fished) site nearest to the reserve boundary was $1.3 \mathrm{~km}$ away. Given that blue cod were larger in the reserve and had relatively limited dispersal (Cole et al. 2000, Davidson 2001), it would be interesting to discover if the CPUE of larger blue cod was higher within a few hundred metres of the reserve boundary.

Other evidence relevant to spillover includes effects on total catch and overall CPUE of the fishery. The significant reduction in CPUE and total catch following the removal of protection of the Sumilon reserve in the Philippines (Alcala \& Russ 1990) is consistent with a reduction of spillover concomitant with a reduction of fish biomass in the reserve. Maypa et al. (2002) and Russ et al. (in press) have shown that the benefits of the reserve to local reef fisheries at Apo Island over a $20 \mathrm{yr}$ period have been higher and/or sustained total catches of reef fishes, increased hook-and-line CPUE, and a reduction in fishing effort. The fishery and tourism benefits generated by the Apo Reserve have enhanced the living standard of the fishing community (Russ et al. in press). McClanahan \& Kaunda-Arara (1996) monitored catch and CPUE close to $(1.5 \mathrm{~km})$ and far from $(6 \mathrm{~km})$ the Mombasa no-take marine park in Kenya, before and after the establishment of the park. The park removed $65 \%$ of the fishing area used by the closest fishlanding site, and about $65 \%$ of the fishermen left the landing site. Although CPUE had increased by $110 \%$ at this landing site 2 yr after park establishment, total catch was still 35\% lower than before the park was established. Note that a neutral no-take park effect would suggest a $65 \%$ lower total catch. McClanahan \& Mangi (2000) extended this study to show that the CPUE of fish traps, and the mean size of trapped fishes, declined with increasing distance from both the southern and northern park boundaries.

However, no study has demonstrated spillover (net export) unequivocally. An experimental design to do this has yet to be applied at the appropriate time scales (Russ 2002). The present study is 1 of only 3 presenting evidence for the development of spillover over decadal time scales. Our results are consistent with those of Roberts et al. (2001), who studied long-lived reef fishes at Merritt Island Reserve in Florida, and with those of Kelly et al. (2002), who studied lobsters at the Leigh Marine Reserve in New Zealand.

It is most likely that the net export of propagules (the 'recruitment effect') from no-take reserves will be of greater importance to the maintenance or enhancement of fisheries than spillover (Russ 2002). Nevertheless, demonstrating spillover, even if the process affects local fisheries in a minor way, is of vital significance to the successful establishment of reserves. Local fishery benefits will generate support for marine reserves (Russ \& Alcala 1996, McClanahan \& Mangi 2000, Roberts et al. 2001). Local fishers at Apo Island are convinced that their catches and catch rates are better because of the presence of the no-take reserve (Russ \& Alcala 1996, Maypa et al. 2002, Russ et al. in press, White et al. unpubl. data). The present study suggests that spillover of Naso vlamingii from the Apo Reserve is an important process affecting this perception of the fishers, and presents convincing evidence that reserves can benefit fisheries by spillover.

Acknowledgements. This project was partially funded by the United Nations Environment Program (1983), the Great Barrier Reef Marine Park Authority (1985) and a Pew Fellowship in Marine Conservation to G.R.R. and A.C.A. (1999-2002). Our thanks to D. C. Zeller and 3 anonymous referees for reading and improving the manuscript.

\section{LITERATURE CITED}

Alcala AC, Russ GR (1990) A direct test of the effects of protective management on abundance and yield of tropical marine resources. J Cons Int Explor Mer 47:40-47

Bellwood DR (1988) Seasonal changes in the size and composition of the fish yield from reefs around Apo Island, 
central Philippines, with notes on methods of yield estimation. J Fish Biol 32:881-893

Cappo M, Eden P, Newman SJ, Robertson S (2000) A new approach to validation of periodicity and timing of opaque zone formation in the otoliths of 11 species of Lutjanus from the central Great Barrier Reef. Fish Bull (Wash DC) 98:474-484

Choat JH, Axe LM (1995) Growth and longevity in acanthurid fishes; an analysis of otolith increments. Mar Ecol Prog Ser 134:15-26

Choat JH, Robertson DR (2002) Age-based studies. In: Sale PF (ed) Coral reef fishes: dynamics and diversity in a complex ecosystem. Academic Press, San Diego, p 57-80

Cole RG, Villouta E, Davidson RJ (2000) Direct evidence of limited dispersal of the reef fish Parapercis colias (Pinguipedidae) within a marine reserve and adjacent fished areas. Aquat Conserv Mar Freshw Ecosyst 10:421-436

Davidson RJ (2001) Changes in population parameters and behaviour of blue cod (Parapercis colias; Pinguipedidae) in Long Island-Lokomohua Marine Reserve, Marlborough Sounds, New Zealand. Aquat Conserv Mar Freshw Ecosyst 11:417-435

Dayton PK, Sala E, Tegner MJ, Thrush SF (2000) Marine protected areas: parks, baselines, and fishery enhancement. Bull Mar Sci 66:617-634

Froese R, Pauly D (1997) Fishbase 97: concept, design and data sources. International Center for Living Aquatic Resources Management, Manila

Galal N, Ormond RFG, Hassan O (2002) Effect of a network of no-take reserves in increasing catch per unit effort and stocks of exploited reef fish at Nabq, South Sinai, Egypt. Mar Freshw Res 53:199-205

Gell FR, Roberts CM (2002) The fishery effects of marine reserves and fishery closures. WWF-US, Washington, DC

Hilborn R (2002) Marine reserves and fisheries management-Reply to CM Roberts. Science 295:1233-1234

Jennings S (2001) Patterns and prediction of population recovery in marine reserves. Rev Fish Biol Fish 10: 209-231

Kelly SD, Scott D, MacDiarmid AB (2002) The value of a spillover fishery for spiny lobsters around a marine reserve in northern New Zealand. Coast Manag 30:153-166

Editorial responsibility: Otto Kinne (Editor), Oldendorf/Luhe, Germany
Maypa AP, Russ GR, Alcala AC, Calumpong HP (2002) Longterm trends in yield and catch rates of the coral reef fishery at Apo Island, central Philippines. Mar Freshw Res 53: 207-213

McClanahan TR, Kaunda-Arara B (1996) Fishery recovery in a coral-reef marine park and its effect on the adjacent fishery. Conserv Biol 10:1187-1199

McClanahan TR, Mangi S (2000) Spillover of exploitable fishes from a marine park and its effect on the adjacent fishery. Ecol Appl 10:1792-1805

Rakitin A, Kramer DL (1996) Effect of a marine reserve on the distribution of coral reef fishes in Barbados. Mar Ecol Prog Ser 131:97-113

Roberts CM, Hawkins JP (2000) Fully-protected marine reserves: a guide. WWF Endangered Seas Campaign, Washington, DC

Roberts CM, Polunin NVC (1991) Are marine reserves effective in management of reef fisheries? Rev Fish Biol Fish 1: 65-91

Roberts CM, Bohnsack JA, Gell F, Hawkins JP, Goodridge R (2001) Effects of marine reserves on adjacent fisheries. Science 294:1920-1923

Russ GR (2002) Yet another review of marine reserves as reef fisheries management tools. In: Sale PF (ed) Coral reef fishes: dynamics and diversity in a complex ecosystem. Academic Press, San Diego, p 421-443

Russ GR, Alcala AC (1996) Do marine reserves export adult fish biomass? Evidence from Apo Island, central Philippines. Mar Ecol Prog Ser 132:1-9

Russ GR, Alcala AC (1998) Natural fishing experiments in marine reserves 1983-1993: community and trophic responses. Coral Reefs 17:383-397

Russ GR, Alcala AC (1999) Management histories of Sumilon and Apo marine reserves, Philippines, and their influence on national marine resource policy. Coral Reefs 18:307-319

Russ GR, Zeller DC (2003) From mare liberum to mare reservarum. Mar Policy 27:75-78

Russ GR, Alcala AC, Maypa AP, Calumpong HP, White AT (in press) Marine reserve benefits local fisheries. Ecol Appl

Sanchez Lizaso JL, Goni R, Renones O, Garcia Charton JA and 5 others (2000) Density dependence in marine protected populations: a review. Environ Conserv 27:144-158

Submitted: March 20, 2003; Accepted: August 5, 2003

Proofs received from author(s): October 16, 2003 